\title{
Fórum
}

\section{Szövegempirizmus és analitikus jogdogmatika: jogi elemzés sub specie linguae}

\author{
„A nyelvvel harcolunk. A nyelvvel harcban állunk." \\ (Ludwig Wittgenstein) ${ }^{1}$
}

jogi elemzések módszertana - empirizmus - jogi nyelv - jogdogmatika

A jogi gyakorlat nagyrészt arra irányul, hogy a résztvevők a jog tartalmára vonatkozó kijelentéseket fogalmaznak meg, támogatólag felhívnak vagy éppen vitatnak mások által tett jogi kijelentéseket (pl. a haszonélvező köteles a haszonélvezetébe tartozó épület tetejéröl leesett cserepeket pótolni). Kérdés, hogy milyen szabályok alapján történhet az ilyen jogi kijelentések kialakítása, megalapozása vagy kritikája. A következőkben erre fókuszálva vázolom fel egy jogi módszertan kereteit.

E módszertan, melyet szövegempirizmus és analitikus jogdogmatika névvel illetek, következetesen nyelvközpontú és empirikus, és célja a jogi kijelentések tudományos igényű megalapozása. Viszonylag egyszerü, kézenfekvőnek tünő alaptételen nyugszik: a tudományos igényű jogi kijelentéseknek meghatározott szabályok szerint összefüggésben kell lenniük autoritatív jogszövegekkel. Ez határozza meg a jogi kutatások kívánatos kiindulópontját és elsődleges irányát, csakúgy mint az elméletalkotás feltételeit, vagy más jogi elméletek kritikájának módszertani alapjait. A szövegempirizmus és analitikus jogdogmatika nem fér össze több olyan nézettel vagy megközelítéssel, melyek általánosnak tekinthetők a mai magyar jogi kutatásokban. ${ }^{2}$

* Dr. Blutman László egyetemi tanár, Szegedi Tudományegyetem, Állam- és Jogtudományi Kar; blutman@ juris.u-szeged.hu. A cikk a debreceni Államelméleti Mühely 2014. április 18-i ülésére készített vitaanyag röviditett, átszerkesztett változata. Így a kifejtés módja szokatlan: tételeken, és az azokat megvilágító megjegyzéseken, példákon nyugszik, de összefoglaló jellege miatt nincs részletes argumentáció és támogató hivatkozási apparátus hozzáfüzve. Mivel a vita arra irányult, hogy a szerző a korábbi munkáiban megmutatkozó módszertani tendenciákat, valamint módszertani nézeteit tételszerūen összefoglalja, általánosítsa és megvédje, a szerző az illendőség határait átlépve kénytelen felhívni saját korábbi munkáit.

Wittgenstein, Ludwig: Észrevételek. Atlantisz, Budapest, 1995, 22.

2 Az itt kifejtett módszertan a sárospataki-szegedi jogpozitivista irányzaton alapszik. A sárospataki-szegedi jogpozitivizmuson azt a jogszabályközpontú, alapvetően formalista, analitikus tudományos kutatási vonalat 


\section{Hat kiinduló tétel}

1.1. A tapasztalati valóságban a tények három típusából következtethetünk egy jogi norma létére és tartalmára: (i) emberi cselekvés; (ii) tartózkodás valamely cselekvéstöl; (iii) nyelvi megnyilatkozás (szóbeli, írásbeli). ${ }^{3}$ A modern jogban egy jogi norma tartalmának kellő pontosságú, általános meghatározása csak nyelvi megnyilatkozások alapján és nyelvi megnyilatkozások által lehetséges.

Megjegyzés. Kérdés, hogy létezhet-e, és ha igen, milyen értelemben, a társadalmi (így jogi) normáknak valamilyen rendszere egy hipotetikus, nyelvet nem használó emberi közösségben. Erre itt nem szükséges kitérni: egyszerüen abból a feltételezésből indulok ki, hogy nyelv nélkül norma nem, csak meghatározatlan, alaktalan normatív attitüdök léteznek a közösség egyes tagjaiban, melyek mások magatartásának értelmezése nyomán alakulnak ki.

1.2. A modern jog és a nyelv elválaszthatatlan. ${ }^{4}$ Kapcsolatuk jellemzésére a következő öt (kissé közhelyszerü) megállapítást teszem.

1.2.1. A modern jogban a nyelv lehetővé teszi a jogi normák kifejeződését, közösségivé teszi az egyedi normatív attitüdöket.

1.2.2. A jogi normák sok vonatkozásban a nyelvben, és a nyelv által léteznek.

1.2.3. A nyelvi megjelenés alapvető feltétele a jogi normák érvényesülésének.

1.2.4. A jogi norma megragadásának, felfogásának és elemzésének az alapját a normára vonatkoztatható nyelvi megnyilatkozások képezik.

1.2.5. A jogi norma tartalma és logikai struktúrája - ha van - valahogyan tükröződik (bár nem feltétlenül pontosan) azokban a nyelvi kifejezésekben, melyekben megfogalmazzák.

Megjegyzés. Itt nem csak arról lehet szó, hogy a nyelv segítségével születnek jogi normák, hanem (lételméleti felfogás függvényében) maga a nyelv (jogszöveg) hozhat létre jogi normákat az emberi elmében.

1.3. A jogi normákra releváns nyelvi megnyilatkozások között alapvetően kijelentésekkel (kijelentő mondatokkal) és a kijelentések csoportjaival kell számolnunk. A kijelentések gerincét a jogi fogalmakat jelölő terminusok adják.

értem, mely a pataki jogakadémia első tanárától, Kövy Sándortól (1763-1829) számítva Finkey Ferencen (büntetöjog, 1870-1949) át egészen Nagy Károlyig (nemzetközi jog, 1932-2001) kivehető. Az összekötö kapocs Buza László akadémikus tudományos tevékenysége (közjog és nemzetközi jog, 1884-1969), aki a pataki jogakadémia utolsó tanárainak egyike volt, majd negyven évig Szegeden oktatott. Kézenfekvő kiindulópontnak tekinthető Kövy Sándor: Elementa Jurisprudentiae Hungaricae (Landerer, Cassoviae, 1804) híres és nagyszerü munkája, melyben Kossuth Lajos tanára elismerésre méltó analitikus erőt mutat fel. (Ugyanakkor nem állítom, hogy e jogtudósok minden egyes nézete pozitivistának minősülne).

3 Pontosabban bármilyen ember alkotta jel vagy jelek csoportja ide tartozhat, azonban ezt itt leegyszerüsíthetjük nyelvi megnyilatkozásokra.

4 A jog és nyelv viszonyára magyar nyelven I. a következő tanulmánykötetet: Szabó Miklós-Varga Csaba (szerk.): Jog és nyelv. PPKE, Budapest, 2000; I. ugyancsak Solt Kornél: Valóság és jog. Bíbor, Miskolc, 1997. 32-80; vagy Szabó Miklós: Trivium. Bíbor, Miskolc, 2001. 93-109. 
Megjegyzés. A jogi normák megragadásának alapegységei (i) a fogalmak (terminusok vagy kifejezések); (ii) a kijelentések; (iii) a kijelentések egyes csoportjai (valamint a közöttük lévő kapcsolatok). Kissé leegyszerüsítve, a jogi normák nem egyszerüen léteznek, hanem kijelentések, kijelentések csoportjai - mint nyelvi megnyilatkozások - által léteznek.

1.4. A jogi normák megragadásánál nem lehet elvonatkoztatni attól, hogy milyen nyelvi kifejezéssel ragadjuk meg a normát, és attól sem, hogy milyen, megelőző és rendelkezésünkre álló nyelvi kifejezések közvetítik számunkra a normát. A normákat jelölő jelcsoportoknak (szavak, mondatok) kulcsszerepe van egy norma tartalmának elemzésénél és megállapításánál. A kapcsolódó nyelvi megnyilatkozások változatossága elvezet a normaazonosság kérdéséhez.

Megjegyzés. A nyelvi kifejezésformától nem lehet eltekinteni. Ugyan az abszolút logikai konstrukciókban gondolkodó megközelítések számára nehezen emészthető a nyelvi relativizmus, de ennek realitására sokan rámutattak már Wilhelm von Humboldttól kezdve Benjamin Lee Whorfon át napjainkig.

Nagyon sok kérdés a jogban azon döl el, hogy a gondolatok milyen nyelvi kifejezésformát kapnak. Például egy okozatossági problémákat felvető jogesetnél az események leírásának (tényállás leírásának) nyelvi formája és részletessége döntő az okozati lánc megállapítása szempontjából. Így valamely ok leírását szolgáló egyegy fogalom (pl. a büntetőjogban a kihülés, lövés, rúgás stb.) önmagában is felbontható okozati láncot képező további körülményekre. A leírás részletessége és nyelvi kifejezésformái dönthetik el, hogy mi minősül egy oknak, mi minősül közvetlen vagy éppen közvetett oknak (ez utóbbi enyhítő körülmény lehet büntetőügyekben). Másrészt, az absztrakciós szint, mellyel az okozatosság eredményét (pl. sérülés, halál, veszélyhelyzet, kár stb.) a bíróság leírja, a kumulatív oksági feltételeket (okokat) alternatív okokká alakithatja, és fordítva, mely döntő lehet a felelösség megállapítása szempontjából. ${ }^{5}$

Példa a) A normaazonosság kérdése felmerül az egymástól különböző, de hasonló tartalmat közvetítő nyelvi kifejezések esetén. Itt utalok egy szokásos, ismerős példára. Vegyük a következő három mondatot: (i) „Ne ölj!” (ii) „Az emberölés tilos.” (iii) „Aki mást megöl, büntett miatt ... büntetendő.” A három mondat viszonyára vonatkozóan könnyü olyan következtetést levonni, hogy lényegileg ugyanazt fejezik ki. Azonban az elemzés csak itt kezdődne. Az első mondat felszólító mondat. A második kijelentő mondat, melyben az emberölésröl állítunk egy tulajdonságot (ti. hogy az tilos), ami mégis normatív jellegủ (logikai értelemben aligha kijelentés, mert nem látható igazságértéke). A harmadik mondatban normatív vonatkozása közvetlenül nem a cselekménynek van, hanem a büntetendöségre irányul.

Minderre tekintettel néhány lényeges kérdést érdemes kiemelni. (i) Mire alapozható, hogy a három mondat ugyanazt fejezi ki? (ii) Mi az, amire egyaránt és egyszerre utalhat a három mondat (milyen entitás)? (iii) Létezik a három mondatnak közös „ényege”? (Mi lenne az?) (iv) Milyen átírási szabályai vannak az egyik mondat má-

${ }^{5}$ Blutman László: Okozatosság a jogban: több ok együttes megítélése. FORVM Acta Juridica et Politica, 2011/1., 136 és 141. 
sik mondatra történő konvertálásának? (Nyelvi-logikai értelemben hogy vezethető vissza egyik a másikra? A három mondat közül melyik vezethető vissza a másikra, azaz melyik lesz a normát legjobban tükröző alapmondat?) (v) Milyen feltételek mellett képzelhető el, hogy a három mondat három normát takar? (vi) A „Ne ölj!” vitathatatlanul erkölcsi normát implikáló mondat, de milyen feltételek mellett állítható erröl - ha állítható -, hogy ez egyben jogi norma is? Ezek a kérdések - részbeni trivialitásuk mellett - azért fontosak, mert az elméleti kutatásokban megtörhetik azt a megközelítést, mely a normák nyelvi kifejezésmódjainak másodlagos szerepet tulajdonít.

Példa b) Van olyan helyzet, amikor a sokféle nyelvi megnyilatkozás egyértelmüen egy jogi normára irányul. Ekkor a normaazonosság nem kérdéses, de az egyes megnyilatkozások eltérő tartalma miatt, maga a normatartalom igen. Az Európai Unió jogában jelenleg huszonnégy, egyformán hiteles nyelv létezik, így egy uniós jogi norma huszonnégy, formailag különböző, autoritatív nyelvi megnyilatkozásban jelenik meg. E nyelvi változatok között lehetnek tartalmi különbségek, és a normatartalom meghatározásának sajátos technikái alakultak ki, melyeket az Európai Unió Bírósága rögzített. ${ }^{6}$

1.5. A magyar elméleti jogi kutatásokban megfigyelhető tendencia, hogy a jogi nyelv által felvetett kérdéseknek, a jogi normák nyelvi kifejezésformáinak (nyelvhasználati módoknak) legfeljebb másodlagos szerepe van. A szokásos megközelítés (valamilyen alapon, valamilyen helyzetben) elgondol egy jogi normát (jogi jelenséget), melynek lehetnek különböző nyelvi megjelenési formái, de ezek rendszerint mellékesek, felcserélhetők, nyelvi-logikai kapcsolatuk reflektálatlan. A nyelvi kifejezésformáktól elvonatkoztatott jogi norma (jogi jelenség) válik aztán részévé következtetéseknek, érvelési láncolatoknak. ${ }^{7}$

Példa. Az alapjogok korlátozásánál a magyar alkotmánybíróság gyakorlatában alkalmazott ún. szükségességi-arányossági teszt számos kérdést vet fel. A legelső ilyen kérdés, hogy ténylegesen egy vagy több teszt van-e, amelyre az absztrakt kifejezés utal. Az AB gyakorlatában elkülönítettem tizenkét nyelvi formulát, és ezzel a teszt lehetséges alkotóelemeit, majd kimutattam, hogy az AB esetenként különböző tartalmú teszteket alkalmaz ugyanazon elnevezés alatt, illetve rámutattam a helyenként meghatározatlan vagy inadekvát, vonatkozó nyelvhasználatra. ${ }^{8} \mathrm{~A}$ szokásos megközelítés ellenben az, amely eleve egy tesztet tételez (absztrakt jogi jelenségként), annak bizonyos jellemzőket tulajdonít, majd a nyelvi kifejezések használatát mellékesnek tekintve vagy figyelmen kívül hagyva, a tételezett absztrakt dogmatikai konstrukcióból (mint ideából) deduktív levezetésekkel próbál megállapításokat tenni az alkotmánybírósági gyakorlatról. Ez aztán vagy téves következtetésekhez vezethet [pl. az olyan következtetés, hogy az AB általában háromágú tesztet alkalmaz

${ }^{6}$ PI. a 6/74. sz., Johannes Coenrad moulijn v. Bizottság ügyben 1974. november 21-én hozott ítélet [EBHT 1974., 1287. o.]; a T-143/89. sz., Ferrière nord SpA v. Bizottság ügyben 1995. április 6-án hozott ítélet [EBHT 1995., II-917. o.].

7 Ez általánosítás, természetesen tudatában vagyok például a jogi nyelvvel kapcsolatos miskolci kutatásoknak (Szabó Miklós).

8 BLutMan László: Az alapjogi teszt a nyelv fogságában. Jogtudományi Közlöny 2012/4. 145-156. 
(megfelelőségi, szükségességi és arányossági kritérium)]. Vagy éppenséggel nem vezet eredményre ( $\mathrm{pl}$. nem tudván eldönteni, hogy a lehetséges legkevésbé korlátozó eszköz formulája az arányossági vagy a szükségességi teszt része-e). ${ }^{9}$ Mindez arra utal, hogy a kérdéses teszt vagy tesztek számát, jellemzőit az $A B$ határozatok szoros vizsgálatával kell megállapítani (induktív megközelítés). A fenti kérdések eldöntésének ismérvei az $A B$ határozatok átfogó vizsgálata által számbavett, feltárt, elemzett, szelektált (vonatkozó) nyelvi kifejezésrendszerben jelennek meg, nem pedig platóni ideaként tételezett absztrakt dogmatikai konstrukciókban.

Megjegyzés a) Bár aligha van olyan kutató, aki elvileg megkérdőjelezné a nyelv szerepét a jogban, a jogi kutatásokban ennek ritkán látszanak konkrét következményei. A nyelvi kifejezésmódok vizsgálatát háttérbe szorítja, hogy a jogi közbeszéd és tudományos beszéd alapvetően objektivista. ${ }^{10}$ Tételezi, hogy a jog, jogi norma objektíve „van” (egyfajta elmefüggetlen képződményként). A jogi norma létrejön, nyelvi kifejezést kap, aztán már objektíve létezik, és lehet „alkalmazni”, „értelmezni”, vonatkozásba hozni más, ugyancsak létező normával. Pedig egy jogi norma nem egy objektív létező, mely mindössze különböző nyelvi kifejezésformákban nyilvánul meg (instanciálódik), hanem egy folytonosan konstruált és rekonstruált, bizonyos szabályok szerint közösségivé tett szellemi entitás, melyre biztonsággal reflektálni legnagyobbrészt nyelvi-logikai szabályok alkalmazásával lehet.

Megjegyzés b) Az objektivista szemléletet számos nyelvi jelenség tükrözi. Íme néhány. A 'jogszabály' (mint törvény, Korm. rendelet stb.) szó használata; vagy annak tételezése, hogy a jogszabály értelmét (ami adott) „ki kell olvasztani”; ${ }^{11}$ vagy hogy egy jogi rendelkezés „értelmet hordoz"; vagy az olyan fordulatok, hogy a "törvény kimondja, miszerint...”; vagy az olyan elméleti megállapítás, hogy a jogi norma objektiváció (az eredeti, „tárgyiasultság” értelmében).

1.6. A kifejtett módszertan által érintett kijelentések hatóköre korlátozott: (i) a jog tartalmára, (ii) a jogra, (iii) a jog tartalmának megállapítására vonatkozó kijelentésekröl van szó (a továbbiakban egyszerüen jogi kijelentések).

Megjegyzés a) Az immanens jogi kutatás természetesen a jog tartalmára irányuló következtetések megfogalmazására irányul. Ez viszont nem választható el a jogra (a jog általános természetére vagy jellemzőire) vonatkozó kijelentésektől. Egy jog tartalmához tartozó kijelentés magáról a jogról is szólhat (pl. egy felelősségi kérdésnél); másrészt az autoritatív jogszövegek tartalmaznak általában jogra vonatkozó megállapításokat is. Itt a jogfilozófiai és jogdogmatikai vonatkozások elválaszthatatlanok. ${ }^{12}$ Ugyanakkor a jog tartalmára vonatkozó kijelentések konkrét esetekben

9 Ilyen, szokásos felfogást tükröző újabb munka KovÁcs Ágnes: Alapjogok ütközése a bírósági gyakorlatban. PhD értekezés, Debrecen, 2013. 160-167. http://jog.unideb.hu/documents/doktori_nyilvanosvita/ kovacsagnes-ertekezes_titkositott.pdf

10 Úgy tủnik, ez már a modern jogpozitivizmus megjelenésénél is így volt; Austin, John: The Province of Jurisprudence Determined. CUP, Cambridge 1995. 18-20.

11 Az Alkotmánybíróság határozataiban megjelenő fordulat, pl. 58/2001. (XII.) AB határozat, ABH 2001, 527. III/5. pont.

12 Ezen a szinten a tételes jogtudomány és a jogfilozófia (pl. jogi alaptan) neokantiánus elhatárolása nem tartható (pl. Somló, Moór). A jogszövegek ugyanis nemcsak a jog tartalmára reflektálhatnak, hanem közvet- 
nem választhatók el a jog tartalmának megállapitására vonatkozó kijelentésektől (pl. - felfogástól függően - egy értelmezési kérdés eldöntéséhez felhasznált morális elv a jog tartalmaként is szemlélhető, de pusztán eszköz is lehet az értelmezés során).

Megjegyzés b) Külön kérdés, hogy a jog müködésével kapcsolatos, szociológiai vagy történeti jellegű elméleti kijelentésekre az itt felvázolt módszertan mennyiben alkalmazható. E kérdéssel itt nem foglalkozom, mert a módszertan az immanens jogi kutatásra vonatkozik.

\section{A szövegempirizmus és analitikus jogdogmatika módszertani körvonalai}

A módszertanra vonatkozó alaptételeket a következők szerint foglalom össze.

2.1. Az immanens (a jogra, a jog tartalmára, valamint a jog tartalmának megállapitására irányuló) elméleti jogi kutatásnak kiindulásként mindig a joggal kapcsolatos nyelvre, nyelvi kifejezési formákra (a nyelvhasználatra) kell irányulnia.

Megjegyzés a) Ez a tétel különösképpen fontos a jogi fogalmak jellemzőinek leírásánál. Például a 'jog' jelentésének, értelmének kutatásakor, azt nem mint társadalmi gyakorlatot vagy társadalmi jelenséget, nem mint fogalmat, hanem mint nyelvi jelenséget (terminust) kell tekinteni. Nem a 'jog' szó segítségével kell leírni a jog különböző megnyilvánulásait, hanem a diskurzusnak a 'jog' szó alkalmazásáról kell szólnia, a használati módjait kiszürve a gyakorlatból. ${ }^{13} \mathrm{~A}$ nyelvhasználat módjai közvetlenül vagy közvetve tükrözik, hogy a hétköznapi vagy szakmai nyelvet használók milyen felfogást képviselnek a jog mibenlétéröl, milyen tulajdonságokat tulajdonítanak a jognak. ${ }^{14}$

Megjegyzés b) A jog absztrakt terminusai és kifejezései nem vizsgálhatóak elszigetelten. A kapcsolódó fogalmak és jelentések nagyban függnek azon helyzetektöl, melyekben használják őket (kontextus-érzékenység). A nyelvhasználati mód feltárása megvilágíthatja a szemantikai-szintaktikai összefüggéseket, ami további levezetésekre, összehasonlításokra, elhatárolásokra, általánosításokra, új fogalmi összefüggések tételezésére ad alkalmat (logikai kapcsolatok). („Értetlenségünk egyik fő forrása, hogy szavaink használatát nem látjuk át." - Wittgenstein) ${ }^{15}$

Példa. A tétel alkalmazására példa a 'jog'terminus hétféle, jellegzetes használati módjának (tulajdonképpen hétféle értelmének) elkülönítése a Polgári Törvénykönyvben (2013. évi V. törvény), melynek alapja a törvényben elöforduló, a 'jog' szót tartalmazó konkrét jogi rendelkezések nyelvi-logikai elemzése. ${ }^{16}$

ve vagy közvetlenül utalhatnak a jog általános (tartalomfüggetlen) formai jellemzöire is. Vö. Somıó Bódog: Jogbölcsészet. Bíbor, Miskolc, 1995. 10.

13 A nyelvi megközelítéssel már John Austin is próbálkozott, de a megközelítést élesen elveti a legtöbb modern jogfilozófus, I. pl. RAz, Joseph: The problem about the Nature of Law. In RAz, Joseph: Ethics in the Public Domain. Clarendon, Oxford 1996. 195-198. Vö. „a jogfilozófia nem lexikográfia” SHAPIRO, Scott J.: Legality. Harvard University Press, Cambridge 2011. 7.

14 Anyelvi fordulat igénye a jog szociológiai elméleteiben is felmerült, I. NELKEN, David: Can there be a Sociology of Legal Meaning? In: Nelken, David (szerk.): Law as Communication. Darthmouth, Aldershot, 1996. 107-128.

15 Wittgenstein, Ludwig: Filozófiai vizsgálódások. Atlantisz, Budapest, 1998. 81.

16 BLutMan László-GöRÖG Márta: Alapvető alanyi jogi pozíciók a Polgári Törvénykönyvben (2013), Jogtudományi Közlöny 2013/6. 273-285. 
2.2. A vizsgálatnak nem általában a joggal kapcsolatos nyelvre, hanem elsősorban az elsődleges és másodlagos jogszövegekben megnyilvánuló nyelvre kell koncentrálódnia (az előző tétel szűkítése).

Megjegyzés a) A jogszövegeket három részre osztom. (i) Elsődleges jogszövegek, azaz a hivatalos közlönyökben megjelenő jogszövegek (a jogalkotás nyelve). (ii) Másodlagos jogszövegek, az alkotmánybíráskodásban, a bírósági gyakorlatban és a közigazgatásban keletkező határozatok nyelve (az autoritatív joggyakorlat nyelve). (iii) Harmadlagos jogszövegek, mely a jogi jelenségek, az elsődleges és másodlagos jogszövegek, a joggyakorlat leírásának tudományos igényű elemzése során keletkeznek (a jogtudomány nyelve).

Megjegyzés b) Az elsődleges jogszövegek elemzése szokásos, sőt triviális a szakjogági tudományokban, de ezen elemzések elsődleges célja a jogszövegek mögé felépíthető dogmatikai összefüggések és konstrukciók, valamint e jogszövegek lehetséges értelmezésének bemutatása, és nem a jogszabályok konkrét nyelvi kifejezéseinek nyelvi-logikai elemzése. Az igazi hiány a másodlagos jogszövegek elemzésénél mutatkozik a mai magyar jogtudományban. A joggyakorlat (pl. bírósági határozatok) hivatkozása rendszerint a jogszabályok értelmezésének példájaként vagy ellenpéldájaként jelenik meg, de nem terjed ki a másodlagos jogszövegek következetes és átfogó nyelvi-logikai elemzésére.

2.3. Az elméleti jogi kutatásnak alapvetően az autoritatív (elsődleges és másodlagos) jogszövegekben (és a kapcsolódó harmadlagos jogszövegekben) használt szavak, kifejezések és kijelentések használati módjainak leírásából (nyelvhasználat feltárása), majd nyelvi-logikai elemzéséből kell kiindulnia. ${ }^{17}$

Megjegyzés a) A nyelvi és logikai elemzés nehezen választható el (a nyelv kémiája a logika - Brassai Sámuel).${ }^{18}$ A nyelvi elemzés alatt elsősorban szemantikai és szintaktikai elemzést értek. A pragmatikának lényegében nincs szerepe az elsődleges és másodlagos jogszövegeknél, mert azok kötött, meghatározott körülmények között és formában jelennek meg (jogszabályok, bírósági határozatok stb.). A logikai elemzés kifejezés a formális logikára és a nem-formális logikára egyaránt utalhat. ${ }^{19}$

2.4. Az elsődleges és másodlagos jogszövegek nyelvhasználatának feltárásán (és az ezt szolgáló nyelvi-logikai elemzésen) alapuló módszertant a szövegempirizmus szóval jelölöm, mely elsősorban a kiindulópontra utal; az alkalmazott műveletek nem maradnak meg a klasszikus empirikus módszerek keretein belül.

Megjegyzés a) Az elnevezés arra utal, hogy az elemzés (és bármilyen általánosítás, elméletalkotás) alapjai, a joggal kapcsolatos társadalmi gyakorlatban keletkező,

17 A kijelentés szót tágabban használom, mint a logikában szokás. Kijelentés alatt értek bármely állítást tartalmazó mondatot, függetlenül attól, hogy az rendelkezik-e igazságértékkel (kijelentő mondatok). Jogi kijelentés alatt a jogra, a jog tartalmára, és a jog tartalmának megállapítására vonatkozó kijelentéseket értek ( $p l$. mit mond a jog, és ebböl milyen következmények adódnak).

18 Brassal Sámuel: A módszerröl. Stein, Kolozsvár, 1892. 82.

19 Emiatt ez nem jogi formalizmus sem Max Weber-i, sem a ma használt, szokásos értelemben; I. Brooks, Roy L.: Structures of judicial decision making from legal formalism to critical theory. Carolina Academic Press, Durham (N.C.) 2005. 31-35, 37. A szemantikai szabályok és a nem-formális logika alkalmazása miatt, egy jogszövegböl nem feltétlenül „vezethető le” egy egyedüli helyes megoldás. 
egyes, objektíve adott jelcsoportok lesznek (elsődleges és másodlagos jogszövegek mint empirikus nyelvi tények). ${ }^{20}$ Ez a megközelítés párhuzamba állitható a filozófiában alkalmazott tapasztalatalapú ismeretelméleti megközelítéssel. Itt az elsődleges és másodlagos jogszövegek a tapasztalat részeként jelennek meg (nyelvi tények), melyekröl kijelentéseket lehet tenni (harmadlagos jogszövegekben, jogi közbeszédben stb.). ${ }^{21}$ Ebben a metszetben a jogi tudás a jogra, a jog tartalmára, valamint a jog tartalmával kapcsolatos megállapításokra vonatkozó kijelentések többé-kevésbé összefüggő rendszeréből áll, és ezen tudás alapját az elsődleges és másodlagos jogszövegek képezik. ${ }^{22}$

Megjegyzés b) A tétel nem jelenti Wittgenstein (ma már meghaladottnak tekinthető) elméletének elfogadását, nevezetesen azt, hogy egy szó jelentését pusztán annak használata adja. Tévedés lenne azonban lemondani a nyelvhasználat feltárásáról. A vizsgált szó vagy kifejezés használata egyben konkretizálás és értelmezés is, melyben a szó új kapcsolódási pontjai tárulhatnak fel, újabb kontextusokban kelhet életre, jellemzői más fényben mutatkozhatnak meg. ${ }^{23}$

2.5. A szövegempirizmus legfontosabb célja, hogy lehetöséget és keretet adjon a jogszövegekben elöforduló jogi terminusok által jelölt fogalmak, valamint a jogi kijelentések „logikai földrajzának” (Gilbert Ryle) feltárására. A jogszövegekben tükröződő nyelvhasználat feltárása elválaszthatatlan logikai műveletek alkalmazásától. A szövegempirizmusra ráépül az analitikus jogdogmatika, mely az aktuális nyelvhasználatból kiszürt fogalmak és kijelentések összefüggéseinek elemzésére, és mögöttes logikai-dogmatikai konstrukciók kialakítására irányul.

Megjegyzés a) A tétel a szövegempirizmus lényeges funkciójára kíván rámutatni. Az analitikus jogdogmatikára jellemző fogalomelemzés mindig feltételezi a fogalom elözetes ismeretét (a fogalom elöképe az elemzés elött). ${ }^{24} \mathrm{~A}$ kérdés, honnan jön a fogalomnak ez az előképe, mint az analízis kiindulópontja. A szövegempirizmus ezen a ponton kényszeríti rá az elemzőt, hogy a jogszövegekből kirajzolódó fogalomképből vagy fogalomképekböl induljon ki, ez legyen az analízis alapanyaga (és ne például a saját intuíciója vagy egy tételezett a priori adottság). A saját rejtett előfeltevéseink érvényesítése helyett ki kell szürni mások (jogalkotó, bíróságok) szempontjait is egyegy fogalom körülírására, és azokat alkalmazni késöbb a fogalmi analízis során.

A módszert már Arisztotelész is alkalmazta. Arisztotelész egyes társadalmi jelenségek vizsgálatához úgy kezdett hozzá, hogy először feltérképezte, milyen állás-

${ }^{20}$ Fontos hangsúlyozni, hogy ezen empirizmus alapját (a tapasztalat tárgyát) a nyelvi tények (megnyilatkozások) képezik, mert az empirikus jogtanoknak másféle változata is van. KARÁcsonY András: Jogfilozófia és társadalomelmélet. Pallas Stúdió-Attraktor, Budapest 2000. 38-39.

${ }^{21}$ Ugyanakkor a jogpozitivizmus XX. századi változatai teljesen elszakadtak a filozófiai pozitivizmustól, már legkésöbb Kelsennel kezdődöen; KaRÁcsony: i. m., 41-42.

22 Nem látom tarthatónak azt, a Kant nyomán tett megállapítást, hogy az empirikus jogtan csak a pozitív jog „replikálása.” PI. SzABó Miklós: A jogdogmatika hivatása. In: SzABó Miklós: Jogdogmatika és jogelmélet. Bíbor, Miskolc, 2007. 157. Nem csak az elsődleges jogszövegek minősíthetők empirikus nyelvi tényeknek, hanem a másodlagos jogszövegek is.

23 L. erre Eco, Umberto: Nyitott mü. Európa, Budapest, 1998. 90.

${ }^{24}$ Ahogy már az ókori filozófusok rájöttek arra, hogy egy kérdés helyes feltevéséhez már ismerni kell a válasz lehetöségeit. GRICE, Herbert Paul: Tanulmányok a szavak életéböl. Gondolat, Budapest, 2011. 161. 
pontok léteznek a kérdésben: ez lehetett a hétköznapi vélekedés, a bölcs emberek álláspontja, vagy általános terminusok (pl. barátság) meghatározásánál egyszerüen a hétköznapi nyelvhasználat (endoxa) (Topika, I.1. 100b21-23). Sokszor a nyelvhasználatból szürte ki a vizsgált terminus különböző használati módjait, eseteit, és kezdte ezeket egymásra vonatkoztatva elemezni. Az endoxa a dialektikus vita premisszája (Topika I.10. 104a8-10). ${ }^{25}$

Megjegyzés b) Az empirikus és analitikus eszközök elhatárolása ebben az öszszefüggésben meglehetősen bizonytalan, és egyben vitatott. Már a nyelvhasználat feltárása is feltételez bizonyos szintű nyelvi-logikai elemzést, ugyanakkor a fogalmi analízis egyenesen feltételezi ezt. Mivel itt céltalan az empirikus és analitikus eszközök elhatárolási problémáira részletesen kitérni, ezért a következőkben szövegempirizmusról és ráépülő nyelvi-logikai elemzésről fogok beszélni. A jogszövegek nyelvi-logikai elemzésével elmélyülhet az analízis, és az sokrétüen árnyalt képet adhat a jogról, a jog tartalmáról. Ami a kémikusnak a különböző anyagokkal megtöltött kémcsövek sorozata, az a jogi elemzésben a jogszövegek terminusai, nyelvi formulái és szövegrészletei.

2.6. A szövegempirizmus és analitikus jogdogmatika néhány alkalmazott, jellegzetes alapmüvelete a következő. (Az alábbi müveleteket csak példaszerüen említem: az egyes nyelvi-logikai lépések többféleképpen írhatók le, és kombinációik köre beláthatatlan.)

(1) Egy szó, kifejezés használati módjának leírása, az egyes jelentések, jelentésváltozatok elkülönítése, a fogalmi határok meghúzása, az ellentmondások - mint a problémák forrásának - feltárása. Példa a 'közzététel' terminus ötféle értelme a magyar joggyakorlatban (közjog, jogalkotás), és az ebből fakadó problémák. ${ }^{26}$

(2) Ugyanazon jogi jelenség nyelvi kifejezésformáinak vizsgálata elsődleges és másodlagos jogszövegekben. Példa a) Annak vizsgálata, hogy egy általános joghelyzetet, melyben egy jogalanyt valamilyen körülményre tekintettel kivételesen mentesítenek valamilyen kötelezettség alól, miképpen jelölik a magyar jogszövegek, és e jelölések mennyire adekvátak. (A mentesség, kiváltság, privilégium, immunitás, elöjog, jogi kedvezmény fogalmak elemzése, összevetése és alkalmazásuk kritikája). ${ }^{27}$ Példa b) A szükségesség-arányosság teszt alkalmazása az Alkotmánybíróság gyakorlatában. A teszt nyelvi megjelenésének vizsgálatánál tizenkét, jól elkülöníthető nyelvi kifejezésforma (formula) elkülönítése, majd ezek nyelvi-logikai elemzése, és a teszt (tesztek) különböző erősségü fajtáinak elkülönítése. ${ }^{28}$

(3) Két vagy több terminus vagy kifejezés használatának elhatárolása, egymáshoz való viszonyának elemzése, egy-egy jogi jelenséggel kapcsolatos fogalmi háló felvázolása. Példa a nemzetközi szerződések belső jog részévé tételének vizsgálatánál a következő, elsődleges és másodlagos jogszövegekben előforduló fogalom-

25 Erröl I. BLutman László: A jogi terminusok fokális elemzése: ókori üzenet a palackban? Jogelméleti Szemle 2010/3. http://jesz.ajk.elte.hu/blutman43.html.

26 Blutman László-Csatlós Erzsébet-SchifFner Imola: A nemzetközi jog hatása a magyar joggyakorlatra. HVG-ORAC, Budapest, 2014. 193.

27 BlutMAN-GörÖg: i. m., 279.

28 Blutman (2012): i. m., 145-156. 
rendszer (fogalmi háló) felvázolása és tisztázása egymáshoz való viszonyukban: kihirdetés, közreadás, inkorporáció, transzformálás, beiktatás, közzététel, 'közhirdetés', nyilvánosságra hozatal, becikkelyezés, promulgáció, törvénybe foglalás, jogszabályba foglalás. ${ }^{29}$

(4) A joggal kapcsolatos kijelentések rejtett elöfeltevéseinek és implikációinak feltárása. A nyelvhasználat logikai földrajzának felvázolása magában foglalja annak felderítését, hogy egy joggal kapcsolatos kijelentés milyen más, általános állításokat feltételez, és milyen más állítások következnek belöle, milyen következményei vannak. Példa a nemzetközi jogi felelősség elemzésénél 'a felelősség a jogsértővel szembeni szankciók alkalmazásában áll' tartalmú kijelentés vizsgálata. ${ }^{30}$ Át kellett tekinteni, hogy milyen elvi előfeltételei vannak egy ilyen, alapvető kijelentésnek, és föleg, milyen következményei léteznek (pl. egyes, nemzetközi jogi jelenségek értékelésénél és magyarázatánál). A kijelentésböl folyó elvi következmények felvázolásánál megkülönböztettem a 'szankció' terminus ötféle használatát, (mely önmagában is meghatározatlanná teszi a kijelentést). ${ }^{31}$

2.7. A vizsgált jogi nyelvhasználat alapjául szolgáló jogszövegek kiválasztása és behatárolása nagyban függ a vizsgált nyelvi kifejezésformáktól és a vizsgálat szempontjaitól. A megközelítések különbözhetnek, íme néhány jellegzetes példa.

(1) Példázás jogszövegekkel. Tipikus lehet, amikor egy joggal kapcsolatos szót vagy kifejezést eleve adottnak veszünk, és csak példázzuk a használatát különbözö, konkrét jogszövegek felhívásával. A tömegesen előforduló szavak, kifejezések vizsgálatánál ez kézenfekvő eljárás.

(2) Egy adott jogszöveg vizsgálata. A vizsgálat irányulhat egy adott jogszöveg átfogó, de bizonyos szempontú vizsgálatára (pl. egy határozat vagy egy jogszabály). Példa: az Alkotmánybíróság 61/2011. (VII. 13.) AB határozatában milyen kijelentések és miképpen utalnak annak a lehetőségére, hogy léteznek alkotmányfeletti normák, milyen módon egyeztethetők össze ezek a kijelentések, és az értelmezett (átalakított) kijelentések alapján milyen szerepük, hatókörük lehet az ilyen normáknak. ${ }^{32}$

(3) A jogszövegek behatárolt körének nem kimerítö vizsgálata. A vizsgált jogszövegek köre ugyan behatárolt (pl. az Alkotmánybíróság vagy egyes ítélőtáblák határozatai), azonban ezen belül a vizsgálat nem teljeskörü. Példa a) Az Európai Unió Bírósága (ezen belül a Bíróság) határozataiban milyen nyelvi kifejezésformákban utal az uniós irányelvek belső jogokban kifejtett hatályára, és ezek a nyelvi kifejezésformák alapján hányféle típusát különböztethetjük meg ezen uniós jogi normák

29 Blutman-Csatlós-Schiffner: i. m., 192-197.

30 A kijelentés Nagy Károly tétele, I. NAGY Károly: Az állam felelőssége a nemzetközi jog megsértése miatt. Akadémiai, Budapest, 1991. 39.

31 Blutman László: Nagy Károly felelösség-elmélete és a Nemzetközi Jogi Bizottság tervezete. In: Balogh Elemér-Blutman László (szerk.): Az államok nemzetközi jogi felelőssége - tíz év után. In memoriam Nagy Károly (1932-2001). Pólay Alapítvány, Szeged, 2013. 14-15.

32 BLutMAn László: Az Alkotmánybíróság és az alkotmány feletti normák: könnyű liaison elkötelezettség nélkül? Közjogi Szemle 2011. december, 1-11. 
joghatásainak. $\left.{ }^{33} P e ́ l d a ~ b\right) ~ A z$ ok és okozat együttes elöfordulásának általános szabályszerüségére utaló regularitás, mint valószínűségen alapuló okazonosító mérce (Hume) milyen nyelvi kifejezésformákban jelenik meg a magyar bírói gyakorlatban (és a magyar jogirodalomban). ${ }^{34}$

(4) A jogszövegek behatárolt körének célhoz kötött, kimerítő vizsgálata. A magyar jogirodalomban nem használt megközelítés, ${ }^{35}$ amikor a joggyakorlat egy szeletét (jogi korpusz) teljeskörü és szisztematikus, textuális vizsgálatnak vetjük alá egy bizonyos szempontból (jogi korpuszvizsgálat). Példa: az Alkotmánybíróság 2011. december 31-ig hozott, azon 322 határozatában, ahol a nemzetközi jog értelmezési támpont volt, milyen nyelvi kifejezésformát kapott a nemzetközi jog „figyelembevétele”, és e nyelvi kifejezésformákból mennyiben lehet következtetni arra, hogy a nemzetközi jog az érvelésben milyen súllyal szerepelt. ${ }^{36}$

Megjegyzés. A jogi korpuszvizsgálat, mint szövegvizsgálat, nem csak a nyelvhasználatra irányulhat (szemben a nyelvészetben alkalmazott korpuszvizsgálattal). Ez alapja lehet más szempontú, kvantitatív módszerek alkalmazásának is (nyelvilogikai elemzés nélkül). Egyszerū statisztikai eredmény például az, hogy a Kúria (Legfelsöbb Bíróság) a 2007. január 1. és 2011. december 31. között hozott, 11271 darab anonimizált határozatában hányszor hívta fel összesen a kettős adóztatás elkerüléséről szóló 1977-es magyar-német egyezményt. Ez azonban érthetően kívül esik az itt felvázolt módszertani kereteken. ${ }^{37}$

2.8. A jogszövegekben az egyes szavak és kifejezések használata jelentősen eltérhet egymástól. A következetesen eltérő nyelvhasználat utalhat arra, hogy az adott terminusnak több értelme van, és mögötte több fogalom húzódik meg. (Az erényt kerestem, és számos erényt találtam - Szókratész. $)^{38} \mathrm{~A}$ módszertan célja, hogy a nyelvhasználatban mutatkozó többértelmüséget kimutassa, és következményeit elemezze.

Megjegyzés. Ez a tétel arra utal, hogy a jogi fogalmak a joggyakorlatban számos változáson eshetnek át, a szaknyelvi terminusok mögött új fogalmak alakulhatnak $\mathrm{ki}$, mely folyamatok a jogszövegekben tükröződnek, és azokból kiszürhetők. Az elemzés csak akkor lehet adekvát, ha a jogi fogalmakat mint nyelvi kifejezésekben megjelenő entitásokat vizsgálja. Ez, a konvencionalizmust és relativizmust sugalló felfogás eleve kérdésessé tesz például olyan megközelítést, hogy az általánosan használt 'jog' szóhoz egy fogalom tartozna (Hart), ${ }^{39}$ vagy a „Nyugatnak” lenne egy

33 Blutman László: Az Európai Unió joga a gyakorlatban. HVG-ORAC, Budapest, 2013. 393-394.

34 BLutMan László: Egy elhanyagolt okazonosító mérce: a regularitás a büntetőjogban. In: Juhász ZsuzsannaNagy Ferenc-Fantoly Zsanett (szerk.): Sapienti sat... Ünnepi kötet dr. Cséka Ervin professzor 90. születésnapjára. Szeged, 2012. 69-79.

35 Vannak ritka kivételek, pl. ZöDı Zsolt: A korábbi esetekre történő hivatkozások mintázatai a magyar bíróságok ítéleteiben. MTA Law Working Papers 2014/1., különösen 26-52. http://jog.tk.mta.hu/uploads/files/ mtalwp/2014_01_Zodi_Zsolt.pdf.

36 Blutman-CsatLós-SchifFNeR: i. m., 434-446.

37 Uo., 460.

38 Kerényi Grácia fordításában: „....az erényt kerestem és, íme egy egész méhrajnyit találtam nálad egy rakáson.” Menón. Platón összes müvei. I. Európa, Budapest, 1984. 648.

39 HART, Herbert L. A.: A jog fogalma. Osiris, Budapest, 1995. 
jogfogalma (Szmodis), ${ }^{40}$ vagy akár egy közösségnek lenne szükségszerüen egy fogalma a jogról (Raz). ${ }^{41}$

2.9. A jogszövegekben mutatkozó eltérö nyelvhasználat arra is utalhat, hogy a nyelvhasználat zavaros, következetlen és ellentmondásos. A módszer alapvető célja e következetlenségek és ellentmondások kimutatása, nyelvi-logikai magyarázata, és hátterének feltárása. A módszer teret ad a kritikai megközelítésnek is.

Megjegyzés. A fenti tétel nem csak a szubjektív, helytelen nyelvhasználatból eredő zavarokra utal. A jogi nyelv a természetes nyelv része, így osztja a természetes nyelv problémáit. Tele van meghatározatlan terminussal, szemantikailag változékony, használata kontextusfüggő, és nem alkalmas arra, hogy az összetettebb gondolatokat pontosan és egyértelműen közvetítse. A jogbiztonságra a legnagyobb eredendő veszély a nyelv tökéletlen mivolta. A nyelvhasználat feltárása után természetes lépés a nyelvi-logikai elemzés, majd a ráépülö kritikai szürés (vö. a következő ponttal).

\section{Szövegempirizmus és analitikus jogdogmatika: a kritikai megközelítés lehetőségei}

3.1. Az empirikus kiindulás (nyelvhasználat feltárása) és a nyelvi-logikai analízis alapot ad a kritikai (normatív) megközelítésnek (harmadik lépcső). Az elsődleges és másodlagos jogszövegek az elemzés során kritika alá vonhatók.

Megjegyzés. Az elsődleges és másodlagos jogszövegek, mint nyelvi tények által keletkeztetett gondolatok ellentmondásosak lehetnek. A kritikai megközelítés elkerülhetetlen, ha általános jogi kijelentéseket kívánunk építeni olyan jogszövegekre, melyek nyelvi zavarokat és ellentmondásokat tükröznek. A szövegempirizmusra rá kell épülnie további nyelvi-logikai elemzésnek, mellyel a nyelvhasználati eltérések magyarázhatók, az ellentmondások kiszürhetök és esetleg feloldhatók. Szemben a természeti tényekkel, az empirikus nyelvi tények (autoritatív jogszövegek), mint emberi konstrukciók kritika alá vonhatók. Az alábbiakban e kritikai megközelítés kereteit vázolom fel.

3.2. A kritika tárgya. A kritika tárgya lehet az elsődleges és másodlagos jogszövegekben: (i) a szavak és kifejezések használata; (ii) az egyes kijelentések felépítése és tartalma; (iii) az egyes kijelentések összekapcsolása.

3.3. A kritika célja (mibenléte). A kritika célja, hogy az elsődleges és másodlagos jogszövegekben a kritikai mércékre alapozva rámutassunk valamely terminus, kijelentés vagy kijelentések helytelenségére (esetenként logikai érvénytelenségére), és egyben kifejtsük az alkalmazott kritikai mércék alapján helyesnek minősíthető megoldást.

40 Szmodıs Jenő: A jog realitása. Kairosz, Budapest, 2005. 121.

41 RAZ, Joseph: Between Authority and Interpretation. OUP, Oxford, 2009. 91. 
3.4. A kritika mércéi. A kritikai mércék a következő körből kerülnek ki (melyek a konkrét elemzésekben kombinálódnak).

3.4.1. Nyelvi (szemantikai és szintaktikai) szabályok.

3.4.2. Logikai szabályok.

3.4.3. Továbbá elsődleges jogszöveg értékelésénél: más elsődleges jogszöveg (az abban foglalt terminusok, kijelentések), illetve mindezekből levezethető vagy mindezekre visszavezethető egyenértékü kijelentések.

3.4.4. Továbbá másodlagos jogszöveg értékelésénél: az elsődleges jogszövegek, valamint magasabb vagy azonos szintủ hatóság által elfogadott másodlagos jogszövegek, illetve mindezekböl levezethető vagy mindezekre visszavezethető egyenértékü kijelentések. ${ }^{42}$

Példa a 'kihirdetés' szó használata azon transzformációs aktusra, mellyel egy nemzetközi szerződést a magyar jogalkotó a magyar jog részévé tesz az Alaptörvény Q) cikk (3) bekezdés második mondata, valamint a 2005. évi L. törvény alapján. Ebben az esetben a kritika általános alapjaként az szolgált, hogy a többértelmü 'kihirdetés' szó alkalmazási feltételeit átfogó szemantikai szabályok alapján a használt terminus nem alkalmas azon folyamat jelölésére, melynek során egy nemzetközi szerződés a magyar jog részévé válik. Ehelyett a megfelelő terminus a 'beiktatás' (régiesen 'becikkelyezés') lenne. ${ }^{43}$

Megjegyzés a) Minden kritikai megközelítésnél kulcs a kritikai mércék mibenléte. Az empirikus kiindulással és a nyelvi-logikai megközelítéssel összhangban a kritikai mércék köre korlátozott. A 3.4.1. és 3.4.2. pontokban jelölt nyelvi-logikai szabályok mérceként szolgálhatnak minden jogszöveg értékelésénél, és alapvetően a következő négy szabálycsoport alkalmazását és érvényesítését jelentik az elemzés során. (i) Szemantikai szabályok: pl. egy szó vagy kifejezés alkalmazási feltételei (kb. jelentése). (ii) Szintaktikai szabályok: pl. állítmányként milyen szófaj szerepelhet. (iii) A formális logika szabályai: pl. egy állításból egy másik állítás létrehozásának szabályai (pl. negáció). (iv) A nem-formális logika szabályai: pl. az induktív általánosításra vonatkozó szabályok.

Megjegyzés b) Az elsődleges jogszövegekben foglalt, kijelentő mondatokként megjelenő konstitutív normák kritikája a másodlagos jogszövegekben tett kijelentésekhez képest korlátozottabb, mert helyességük mércéje sokszor saját maguk léte is lehet. Tegyük fel, hogy egy természetvédelmi jogszabály a védett madárfajok közé sorolja a verebek családjába tartozó 'csiribeket' (Passer ciribus). Azonban ilyen madárfaj nem létezik. Ekkor a kritikai mérce szemantikai szabály: a 'csirib' szó alkalmazási feltételeinek nem felel meg a jogszöveg. Amennyiben a jogszöveg úgy rendelkezne, hogy a 'csirib' szó alatt a házi verebet (Passer domesticus) érti (létező madárfaj), akkor konstituálna egy szemantikai szabályt, mely alapján a kérdéses szó használata helyessé válna. Ilyen szabály híján azonban a szó nem használható utalásként egy olyan madárfajra, mely létezik.

42 A másodlagos jogszövegek elsődleges jogszövegek alapján történő értékelése a jogértelmezés általános kérdéseit veti fel, I. BLutman László: Bírói jogalkalmazás és szöveghủ értelmezés. Jogesetek Magyarázata (JeMa) 2010/4, 94-104.

43 Blutman László: A nemzetközi szerződések 'kihirdetése': fogalmi zavar a közjogban. Iustum Aequum Salutare 2013/4, 185-203. 
Az elsődleges jogszövegek kritikai mércéje legtöbbször és alapvetően szemantikai szabályokon alapul, de kivételesen lehet önmagában logikai szabály is. [Ez alapján lehet kritika alá vetni a központi államigazgatási szervekről szóló 2006. évi LVII. törvény 81 . § (3) bekezdését, mely a következöket rendelte: „Ahol törvény államtitkárt megillető illetményt, illetve juttatásokat említ, azon államtitkárt megillető illetményt, illetve juttatásokat kell érteni." (Hatályban volt 2006. július 1-jétől 2006. december 31-ig.)]

Megjegyzés c) Van, amikor nem lehet a következetlen gyakorlatból a következetlenséget kiküszöbölni a fentiek szerint alkalmazható kritikai eszközökkel. Azonban a nyelvhasználat következetlenségeinek vagy zavarainak kimutatása önmagában érték, mely esetenként nem kíván külön magyarázatot. Példa: A Polgári Törvénykönyvben (2013) időnként az általánosan használt kötelezettség helyett a kötelesség szóval találkozunk. Így nem kötelezettsége, hanem kötelessége van a részvényutalványosnak [3:226. §], a szülönek [4:168. §], a gyámnak [4:251. § (1) bekezdés], a találótársaknak [5:54. § (2) bekezdés], a gondozónak [6:542. §] és a házastársnak [7:80. $\S(4)$ bekezdés]. E jogalanyoknak lehetnek kötelezettségeik is, és a két terminus közötti különbség a mai magánjogi nyelvben és a kódexben sem világos. Az eltérő szóhasználat magyarázata helyett (ami puszta spekuláció lenne), egyszerüen rögzítettük az anomáliát. ${ }^{44}$

3.5. Feltételes kritikai mércék. Vannak egyéb, szokásosan használt kritikai mércék, melyek alkalmazásával a szövegempirizmus és analitikus jogdogmatika nem számol. Példaként néhány (melyek konkrét elemzésekben kombinálódhatnak): (i) a szabályozás tételezett célja (ezt szolgálja-e); (ii) a szabályozás következményei (kívánatosak-e); (iii) etikai, filozófiai tételek, általános elvek; (iv) konvencionális társadalmi szabályok, szokások; (v) jogi elméletekben (harmadlagos jogszövegekben) szereplő kijelentések, tételek stb. Ezen szokásosan alkalmazott kritikai mércék felhasználása korlátozott. Alkalmazhatóságuk attól függ, hogy az ezek tételezését tartalmazó határozott kijelentések visszavezethetők-e (nyelvi-logikai szabályok segítségével) elsődleges vagy másodlagos jogszövegekre, és így beilleszthetők-e a 3.4.3. és 3.4.4. pont alatti kritikai mércék körébe (visszavezethetőség elve).

Megjegyzés. E szokásosan használt kritikai mércék tipikusan retorikai vagy szociológiai jellegüek, így a jogszövegek tudományos igényű, immanens jogi kritikáját önmagukban nem alapozhatják meg. Felhasználásuk hármas feltételhez kötött: (i) határozott kijelentések formájában le kell írni öket; (ii) visszavezethetőnek kell lenniük elsődleges vagy másodlagos jogszövegekre; (iii) alkalmazhatóságuk külön előzetes vizsgálatot igényel, és e kritikai mércék is kritika alá vetendők (hiperkritika). Vö. az elméletkritika feltételeivel, a következő pontban. 


\section{Szövegempirizmus és analitikus jogdogmatika: a teoretizálás lehetöségei}

Strawson írja: „a filozófia első feladata, hogy megvonja önnön határait.”45 Ugyanezt meg kell tennie a jogi elméleti kutatásoknak is. A következő tételek ennek szellemében a teoretizálás határait húzzák meg, melyek tükrözik a szövegempirizmus és analitikus jogdogmatika ismertetett tételeit.

4.1. A jelen összefüggésekben teoretizálás alatt kétirányú tevékenységet értek: (i) a módszertant alkalmazó elemző által végzett általánosításokat, és az így kapott általános kijelentések rendszerbe foglalását; ${ }^{46}$ (ii) a módszert alkalmazó elemző által végzett, mások elméleteire irányuló elméletértékelést (elméletkritikát).

Megjegyzés. A szövegempirizmus és analitikus jogdogmatika - kiindulópontjából következően - elsősorban nem nagy jogi elméletek kialakítására irányul, hanem a jogi nyelv megtisztítására és karbantartására, valamint a jogi kijelentések nyelvi-logikai ellenőrzésére. A módszertan azonban nem zárja ki az általánosításokat, az új dogmatikai modellek kialakítását, és lehetőséget nyújt az elméleti hipotézisek rendszerezett kontrolljára (legyen az a módszertant alkalmazó elemző hipotézise, vagy más elméletben szereplő általános kijelentés).

4.2. A szövegempirizmus és analitikus jogdogmatika egyik célja az általánosságuknál fogva értelem nélküli, vagy éppen értelmezhetetlen kijelentések visszaszorítása vagy kiküszöbölése, és az általánosítások kellő megalapozása. (A jogelméletben a tételek annál értéktelenebbek és használhatatlanabbak, minél absztraktabbak - Kantorowicz. $)^{47}$ Így a módszertan eröteljes ellenőrzés alatt tartja az általánositásokat (és ezzel egyben az elméletalkotást).

Megjegyzés. Az általánosításoknak ebben az összefüggésben két iránya van. (i) A jog tartalmára vonatkozó általánosítások, melyek általános jogi kijelentésekként jelennek meg. (ii) A másodlagos jogszövegekre mint empirikus nyelvi tényekre vonatkozó (az elemző által tett) általánosítások, melyek a joggyakorlatra vonatkozó általánositásokként jelennek meg. A megkülönböztetés lényeges, mert egy konkrét bírósági határozat is tartalmazhat általános jogi kijelentéseket. Ugyanakkor a joggyakorlatra vonatkozó általánosítások tartalmilag vonatkozhatnak a joggyakorlatban előforduló, hasonló általános jogi kijelentésekre is. ${ }^{48}$

4.3. A joggal kapcsolatos kijelentések helyességének alapvető ismérve, hogy nyelvi-logikai szabályok alkalmazásával visszavezethetők legyenek elsődleges vagy másodlagos jogszövegekre (empirikus nyelvi tényekre). ${ }^{49} \mathrm{~A}$ visszavezethetőség is-

45 Strawson, Peter F.: Az érzékelés és a jelentés határai. Osiris, Budapest, 2000. 15.

46 A jellemző gondolati műveletek lehetnek: fölöttes fogalmak alkotása; általánosítások végzése és általános kijelentések felállítása; fogalmak és kijelentések osztályozása, rendszerezése, hierarchizálása stb.

47 Varga Csaba (szerk.): Jog és filozófia. Akadémiai, Budapest, 1981, 60.

48 Hasonló megkülönböztetésre nézve I. Bıвó István: Kolozsvári jogfilozófiai előadások. In: Dénes Iván Zoltán (szerk): Bibó István egyetemi előadásai. Kossuth, Debrecen, 2004. 26.

49 Kérdés, hogy a megfigyelésen alapuló tapasztalati tényeknek lehet-e hasonló szerepe ebben az összefüggésben. Sejtésem, hogy nem. De ez külön tárgyalást igényelne, így ezeket most kizárom a helyességi kritériumok közül. 
mérvének eleget tevő kijelentések, illetve elméletek abszolút értéküek (tudományos igényüek).

Megjegyzés. A fenti módszertan az abszolút értékü általánosítások tekintetében hármas igénnyel lép fel: (i) szilárd alap találása a joggal kapcsolatos kijelentéseknek, beleértve az általános kijelentéseket is (visszavezethetőség elsődleges vagy másodlagos jogszövegekre); (ii) azon kapcsolatok hiányának, vagy azon kapcsolatoknak az átláthatóvá tétele, melyek a használt kijelentéseket összekötik a jogszövegekkel (átláthatóság); (iii) ellenőrizhetőség biztosítása. Ezen követelményeknek leginkább a jogban keletkező jogszövegek és a nyelvi-logikai szabályok felelnek meg. Azon általános kijelentések, melyeknek nincs kimutatható kapcsolódása a jogszövegekhez, látszatproblémákhoz vezethetnek.

4.4. A visszavezethetőség lényege: az általános elméleti jogi kijelentés átalakítása olyan, egyenértékü kijelentésekké, melyek elsődleges vagy másodlagos jogszövegekre vagy azokból levezetett kijelentésekre alapozhatók. Mivel egy-egy kijelentés a benne szereplő szavak, vagy a kijelentés szerkezete miatt csak úgy vezethető vissza a jogszövegekre, ha közbenső, egyenértékủ kijelentéssé vagy kijelentésekké alakítjuk át, az egyenértéküség kritériumának kulcsszerepe van a helyes elemzésben. Az egyenértéküség nyelvi-logikai egyenértéküséget jelent, vagyis a kijelentés átalakítása megfelel a (i) szemantikai; (ii) szintaktikai; (iii) formális logikai; (iv) nemformális logikai szabályoknak.

Megjegyzés. A szemantikai szabályoknak és az informális logika szabályainak alkalmazása nem hozhat egyértelmü (egyetlen helyes) eredményt egy kijelentés átalakításakor. Egy kijelentés többféleképpen is átalakítható, azaz számos, nyelvilogikai értelemben egyenértékü kijelentésként írható át. Ez az eredendő bizonytalanság csak egy mesterséges nyelv alkalmazásával lenne kiküszöbölhető, azonban Leibniz, Frege és Russell álma a jogi nyelvnél természetesen nem realitás, legalábbis a jelenlegi állapotokat tekintve.

4.5. Minden olyan, jogra vonatkozó kijelentés, mely nyelvi-logikai úton teljes mértékben nem vezethető vissza elsődleges és másodlagos jogszövegekre, csak relatív értékü kijelentés. A jogra vonatkozó relatív értékủ kijelentések nem tudományos igényűek: jellegüknél fogva a jogi retorika területéhez tartoznak.

Megjegyzés. A szövegempirizmus és a ráépülő analitikus jogdogmatika kiindulópontja - bármennyire fantáziátlannak tünjön első pillantásra - technikailag sem zárja el a teoretizálás lehetőségét. (A pozitív jognak is van filozófiája - pl. Hugo, Merkel, Bergbohm. ${ }^{50} \mathrm{~A}$ nyelvhasználat vizsgálata a másodlagos jogszövegekben sok esetben rövid utat kínál, akár a legmélyebb filozófiai kérdésekig. (Más kérdés, hogy ez a teoretizálás tipikusan relatív értékü, általános kijelentésekhez vezethet el, mert az általánosítások során felhasznált tételek mindegyike nem vezethető vissza jogszövegekre.) Példa a) Amennyiben a bíróság ítéletében kimondja, hogy a felperesnek mint tulajdonosnak $x, y$ és $z$ feltételek mellett joga van ahhoz, hogy belépjen a tulajdonában lévő, de más által bérelt ingatlanába, felvethető a kérdés, hogy egy ilyen

50 L. erre Pokol Béla: Autentikus jogelmélet. Dialóg Campus, Budapest-Pécs, 2010. 19.; vagy KarácsonY: i. m., 38. 
kijelentés lehet-e igaz (van-e igazságértéke). Amennyiben igaz lehet, milyen feltételek mellett állítható e kijelentésről, hogy igaz. Példa b) Amennyiben az Alkotmánybíróság az alapjogok lényegének korlátozhatatlanságáról szól (alkotmányi szabályt követve), kézenfekvő a felvetés, hogy egy jognak, azaz jogosultságnak (maga is meghatározatlan entitás) lehet-e lényege. Mindez gyorsan elvezet az absztrakt terminusok ontológiai problémáihoz.

4.6. A módszertan alkalmazásában más elméletek (vagyis a harmadlagos jogszövegek) felhasználhatósága korlátozott, mert azok önmagukban nem képezhetik szilárd, ellenőrizhető alapját az általános jogi kijelentéseknek. A harmadlagos jogszövegek (más elméletek, általános elméleti jogi kijelentések) felhasználhatóságának négy jellegzetes esete van:

4.6.1. amennyiben azok közvetlenül elsődleges vagy másodlagos jogszövegek elemzéséhez, értékeléséhez kapcsolódnak, és adalékul szolgálnak az azokról tett általános kijelentésekhez;

4.6.2. amennyiben egyes megállapításai közvetítő kritikai mérceként szolgálnak az elsődleges vagy másodlagos jogszövegekben fellelhető ellentmondásos nyelvhasználat kritikai megközelítésénél;

4.6.3. segítségül szolgálnak egy-egy releváns tapasztalati tény vagy folyamat leírására szolgáló kijelentések helyes leírásában (és így a konkrét terminus alkalmazására vonatkozó szemantikai szabály megállapításánál);

4.6.4. a módszertan segítségével tett általános jogi kijelentésekkel konkuráló, általános kijelentések (elméletek) kritikája a tudományos tisztesség alapján.

Megjegyzés a) A módszertannak nem elsődleges célja az elméletértékelés (elméletkritika), azaz harmadlagos jogszövegek (más elméletek) elemzése és kritikai megközelítése, de a 4.6.2. és 4.6.4. pontokban foglalt eseteknél ez nem kerülhető el. A szövegempirizmus és analitikus jogdogmatika mint módszertan alapján tett jogi kijelentések absztrakciós szintje rendszerint nem magas, és e kijelentések nem állnak össze átfogó, általános elméletekké. (Ennek oka a kiindulópont jellege és a teoretizálás szoros kritériumai.) Emiatt a módszertan alapján tett kijelentések nem egészében, magas absztrakciós szinten ütköznek konkurens tételeket tartalmazó elméletekkel, hanem jellegzetesen konkurens kijelentésekkel ütköznek, melyek mögött egy elmélet áll (elméleti jogi kijelentések). E konkurens kijelentések természetesen lehetnek az adott elmélet kulcstételei, melyen keresztül az elmélet egésze kritika alá kerül.

Megjegyzés b) Az átfogó elméletkritika külön módszertani kérdéseket vet fel, melyeket itt nem elemzek. ${ }^{51} \mathrm{~A}$ probléma nyilvánvalóan az, hogy egy-egy nagy, absztrakt jogi elmélet hatalmas mennyiségü kijelentésböl áll. Ezeknek ugyan csak egy kisebb része jogi kijelentés (jogra, a jog tartalmára, és a jog tartalmának megállapítására vonatkozó kijelentés), ennek ellenére a jogi kijelentések összefüggéseinek átfogó feltárása rendkívüli feladat lenne. A nagyobb elméletek kritikája ezért az alaptételek

51 Például a szuverenitás-elméletek átfogó kritikai szempontrendszerére nézve I. BLuTMAn László: Milyen feltételekkel beszélhetünk értelmesen a szuverenitásról? Egy metaelmélet kiindulópontjai. MTA Law Working Papers 2014/17. 10-16. http://jog.tk.mta.hu/uploads/files/mtalwp/2014_17_Blutman.pdf. 
vagy saroktételek módszeres értékelésére irányulhat, de ezek tartalmának megállapításához sok egyéb elméleti kijelentést is figyelembe kell venni.

4.7. Az elméletkritika az elmélet részét képező nyelvhasználat és kijelentések értékelése meghatározott kritikai mércék alapján. Az elméleti jogi kijelentések (elméletek) értékelésénél a kritikai mércék köre hasonló ahhoz, mint amit az elsődleges és másodlagos jogszövegek esetében láthattunk:

4.7.1. elsődleges vagy másodlagos jogszövegek (az abban foglalt terminusok, kijelentések), illetve mindezekből levezethető vagy mindezekre visszavezethető egyenértékü kijelentések (az ezekre való visszavezethetőség kritériuma);

4.7.2. az elméletben foglalt más kijelentések, vagy az azokból levezethető egyéb kijelentések (az ezekkel való koherencia kritériuma);

4.7.3. nyelvi (szemantikai és szintaktikai) szabályok (mint müveleti szabályok);

4.7.4. logikai szabályok (mint műveleti szabályok).

Megjegyzés a) Az elméletértékelésnél is érvényesíteni kell a teoretizálás korlátait. Példa: Látványos kontrollját jelenti például a jogi analógiára vonatkozó elméleti kijelentéseknek a joggyakorlat, ahol nem találkozunk olyan megkülönböztetéssel, mint az elméletben szokásosan alkalmazott analogia legis és analogia iuris. Korábban kimutattam, hogy e megkülönböztetés hanyagolása a bíróságok által teljesen megalapozott: az analógia ilyen kettéválasztása ugyanis elméletileg sem tartható. ${ }^{52}$

Megjegyzés b) A fentiek alapján a jogra vonatkozó legáltalánosabb tételek (a jogról állított tulajdonságok vagy relációk) is tesztelhetők (pl. 'jogi norma objektiváció'). Itt három alapvető probléma mutatkozik. (i) Az ilyen elméleti kijelentések tipikusan nem a joggyakorlat nyelvét alkalmazzák, tehát e kijelentéseket nyelvi-logikai szabályokkal transzformálni kell (pl. az 'objektiváció' szó átírása a gyakorlat nyelvére). (ii) A transzformáció feltételezi az átalakítandó kijelentések értelmezését, ami lényeges gondot okozhat általánosságuknál fogva (pl. az 'objektiváció', mint fölöttes absztrakt fogalmat jelölő szó értelmezése). ${ }^{53}$ (iii) A másodlagos jogszövegek absztrakciós szintje alacsonyabb, így csak széles áttekintés adhat alapot a másodlagos jogszövegekben előforduló kijelentések relevanciájának megállapításához, és a releváns kijelentések általánosításához (pl. fel kell tárni, hogy az 'objektiváció' szó ekvivalensei milyen összefüggésben kapcsolódnak össze a 'jogi norma' kifejezéssel vagy annak ekvivalenseivel a jogszövegekben szereplö kijelentésekben).

Ugyanakkor két szempont könnyebbé teheti az ilyen vizsgálatot. (i) A bíróságok tesznek általános kijelentéseket a másodlagos jogszövegekben (mint ahogy egyes jogszabályok is megteszik ezt, I. pl. a jogalkotásról szóló jogszabályokat). (ii) A bírósági határozatokban foglaltaknak vannak előfeltevései, melyek feltárhatók, és

52 Blutman László: A jogdogmatika zátonyai: az analógia a magyar jogban. Jogtudományi Közlöny 2008/6. 282-284.

${ }^{53} \mathrm{Az}$ 'objektiváció' terminus önmaga is bőségesen hoz elő értelmezési problémákat, mert mást jelent például Horváth Barnánál, Peschka Vilmosnál, és megint másként használta a Legfelsőbb Bíróság, például a BH 1986. 306. sz. ügyben. 
melyek a jogelmélet általános szintjét is érintik (a jogelmélet rejtett előszó minden jogi döntésnél - Dworkin. $)^{54}$

4.8. A jogra vonatkozó elméleti kijelentések egy csoportja - kivételként - nem vethető alá a fenti kritikai mércéknek. Ezek olyan, a jogszövegekre (is) vonatkoztatható, általános és tartalomfüggetlen kijelentések, melyek a jogszövegekröl, mint nyelvi kifejezésformákról tartalmaznak - közvetlenül vagy levezethetően - állításokat.

Megjegyzés. Az olyan kijelentések, melyek a jogszövegeket vagy azok egy fajtáját, mint nyelvi kifejezésformákat tekintik közvetlenül vagy közvetve, általánosan és tartalmuktól függetlenül inadekvátnak, nem igazolhatók vagy cáfolhatók e jogszövegek alapján. Ilyen kijelentések például: 'a jog csupán szómágia' (Hägerströmnek tulajdonítható tétel), ${ }^{55}$ vagy 'a bíróságok rituális nyelvet használnak' (Hart) stb. Például 'a jog csupán szómágia' kijelentés nem értékelhető másodlagos jogszövegek alapján, amennyiben bírósági határozatokra mint jogszövegekre is értjük. Hiába találkozhatunk ezzel kapcsolatba hozható kijelentésekkel másodlagos jogszövegekben, e megállapítások nem szolgálhatnak mérceként, mert rájuk is kiterjed a kijelentés hatóköre (azaz maguk is részei a 'szómágiának'). A visszavezethetőség logikai lehetetlensége miatt ezek a kijelentések eleve nem lehetnek abszolút értékű jogi kijelentések.

4.9. A módszertan nem zárja ki az olyan elméletalkotást sem, mely a fenti ismérveknek nem felel meg. Mindössze korlátozott szerepet szán neki. A jogszövegekre vissza nem vezethetö, bizonytalan feltételezésekre támaszkodó elméleteknek relatív értékük van. A relatív értékủ elméletek értelmezési keretet adnak jogi jelenségek értelmezéséhez vagy értékeléséhez, de nem tarthatnak igényt kizárólagosságra. Relatív értéküket (pragmatikus értéküket) magyarázó erejük, a belátások eredetisége és frissessége, valamint retorikai erejük adja.

Megjegyzés a) Ahogy Kant írta, minden fogalomnak szüksége van „a lehetséges tapasztalathoz szolgáló, készen talált adatokra”, azaz empirikus szemléletekre. „E vonatkozás nélkül nem rendelkezik objektív érvénnyel, hanem puszta játék, melyet vagy a képzelőtehetség, vagy az értelem üz képzeteivel." ${ }^{.56}$

Megjegyzés b) Mivel a szövegempirizmuson alapuló módszertan legfontosabb célja az átláthatóság és ellenőrizhetőség, nem szorítja vissza az értelmes jogi diskurzus lehetöségét a minimális szintre. Ehelyett a diskurzus alapjait kívánja megszilárdítani, és ebböl a szempontból négy szint különül el (a különböző szinteken megjelenő megállapítások alapjai egyre bizonytalanabbak): (i) a nyelvhasználat leíró jellegủ feltárása (szövegempirizmus); (ii) analitikus (jellegében nyelvi-logikai) dogmatikai elemzések; (iii) abszolút értékü (tudományos igényű) általánosítások, elméletalkotás, kritikai mércék alkalmazása (a visszavezethetőség kritériumának érvényesülése mellett);

54 Dworkin, Ronald: Law’s Empire. Harvard University Press, Cambridge (Ma), 1986. 90.

55 Valószínü, hogy Hägerström soha nem mondta így szó szerint (inkább Lundstedt terjesztette ennyire ki), de a kijelentés érzékelteti következtetéseinek irányát; I. OLIVECRONA, Karl: The Legal Theories of Axel Hägerström and Vilhelm Lundstedt. Scandinavian Studies in Law Vol 3. (1959), 133. http://www.scandinavianlaw.se/ pdf/3-5.pdf.

56 KANT, Immanuel: A tiszta ész kritikája. Atlantisz, Budapest, 2009. 260. 
(iv) sajátos értelmezési keretként müködő, relatív értékü (retorikai) általánosítások, elméletalkotás korlátozott célú elismerése (a visszavezethetőség kritériumának érvényesülése nélkül).

\section{Hat pragmatikus érv a szövegempirizmus és analitikus jogdogmatika alkalmazása mellett}

Álláspontom az, hogy a jog elméleti kutatásának - amennyiben tudományos, és nem retorikai igénnyel lép fel - elsődlegesen a jogi nyelv megtisztítására és karbantartására kell irányulnia (beleértve annak fogalmi hátterét). A szövegempirizmus és a nyelvi-logikai analízis célja, hogy a jogdogmatikai ellentmondásokat, problémákat megmutassa, és lehetőség szerint kiküszöbölje. Ezen tétel alátámasztására hat célszerüségi érvet hozok fel.

5.1. Ezzel a magyar jogi elméleti kutatások egy általános hatású eszközt alkalmaznának. A modern jog nem választható el a nyelvtől, és a jogi nyelv nyelvi-logikai analízise a jog minden területén alkalmazható.

5.2. A magyar jogi elméletek nagyobb hatást tudnának gyakorolni a joggyakorlatra. A joggyakorlatra elhanyagolható hatással vannak az elvont elméleti eredmények (amennyiben ilyen hatás egyáltalán kimutatható). A joggyakorlatot leghamarabb a megalapozott, világos, konkrét másodlagos jogszövegekre (határozatokra) vonatkozó, kényszerítő erejü nyelvi-logikai kritika érheti el.

5.3. Az általános jogi dogmatikai elméletek közvetítőként szolgálhatnának a szakjogágak tudományterületei között, melyek ma lényegében egymástól elszakitva építgetik saját jogi nyelvüket és dogmatikai rendszereiket (egy alapdogmatikai rendszer kialakításának, és egyben általános dogmatikai kontroll alkalmazásának lehetösége).

Megjegyzés. Azt, hogy létezhet bizonyos absztrakciós szinten egyfajta közvetítö alapdogmatika, mely átfoghatja akár a büntetőjogot és a magánjogot is, az okozatosság vizsgálatával igyekeztem bemutatni. Az okozatossági kérdéseknek van egy olyan fogalmi-logikai szintje, amelynek vizsgálata többé-kevésbé független attól, hogy milyen jogághoz tartozó területen merülnek fel. Ezen a szinten az okozatossági kérdések vizsgálhatók anélkül, hogy kevernénk a felelősségre vonatkozó következtetésekkel, ami már jogág-specifikus. ${ }^{57}$

57 Blutman László: Okozatosság, oksági mércék és a magyar bírói gyakorlat. Jogtudományi Közlöny 2011/6. 309-320. Ez a gondolat természetesen nem új, már a következő alapmű is erre épült: HART, Herbert L. A.Honoré, Anthony: Causation in the Law. Clarendon Press, Oxford, 1985. 
5.4. A nyelvi-logikai elemzés középpontba állításával a jogelmélet némileg távolodna a retorikától („érvtalálás művészete”) és a relatív értékü, vitatott, általános kijelentések alkalmazásától, ugyanakkor közeledne a hagyományos értelemben vett tudományokhoz (természettudományokhoz), azok kötöttebb módszertanához.

5.5. A jogi elméletek elkerülhetnék, hogy értelem nélküli vagy megválaszolhatatlan kérdésekre keressenek választ (pl. mi a jog), és eljussanak helyes kérdésfeltevésekig.

5.6. A számítógépes nyelvészet jelentős lépéseket tett azon irányban, hogy bizonyos mértékben formalizálja a jogi szaknyelvet is (gépi jogszöveg-elemzések, jogi ontológiák felállítása, szöveggenerálás stb.). A nyelvtechnológia feltételezhető jövőbeni sikerei szükségképpen hatással lesznek a jogalkotásra is (pl. rendeleti jogalkotás), ami például formalizáltabb elsődleges jogszövegekben (kötöttebb nyelvi-logikai struktúrákban), a stipulatív definíciók szaporodásában nyilvánul majd meg. E változásra a jogi elméleti kutatásoknak is fel kell készülni, sőt elébe is menni, amihez módszertani keretet a szövegempirizmus adhat.

\section{Abstract}

In the article the author outlines the basics of a legal methodology (called textempiricism and analytical legal doctrine), which is consistently language-oriented and empirical. It rests on a relatively simple, seemingly obvious assertion: in order to qualify as scientific proposition, legal propositions need to correlate to authoritative legal texts as empirical linguistic facts. This stance defines the necessary starting point for and primary direction of legal research as well as the terms of legal theorizing, or the methodological foundations of the critique of general legal statements. 